Doświadczenie mistyczne w religiach niechrześcijańskich.

Perspektywa filozoficzna

„Filozofia Chrześcijańska” 17 (2020), s. 95-113

\author{
KATARZYNA PACHNIAK \\ Uniwersytet Warszawski \\ Wydział Orientalistyczny
}

\title{
Medytacja i doświadczenie mistyczne w okresie formatywnym sufizmu
}

Pozornie wydaje się, że trudno znaleźć religię, której doświadczenie mistyczne byłoby tak obce jak w islamie. Doktryna bezkompromisowej Bożej jedności i jedyności oraz absolutnej Bożej transcendencji zupełnie nie współgra z chęcią człowieka, aby jak najściślej połączyć się z Bogiem, na jeden wyjątkowy moment ekstazy zlać się z Nim w jedno. Koran, święta księga muzułmanów, wyznaczająca podstawy życia religijnego, ale także wszystkich innych jego aspektów, uważana przez muzułmanów za czyste słowo Boże, wypowiada się w tej sprawie kategorycznie: Bóg jest jeden i nie można przypisywać Mu żadnych „towarzyszy”. Jest to grzech szirku, surowo w islamie karany, tym bardziej że w tym przypadku towarzyszem Boga miałby być człowiek, nawet jeśli miałoby to trwać jedynie krótką chwilę. $Z$ drugiej jednak strony, w tym samym Koranie czytamy, że Bóg jest „bliższy [człowiekowi] od tętnicy szyjnej” (K 50:15) ${ }^{1}$. Z pewnością ta dwuznaczność, ale także doświadczenia mistyczne religii starszych niż islam sprawiły, że tendencje mistyczne zaczęły się w nim rozwijać niemalże od samego początku istnienia tej religii, powstałej w pierwszej połowie VII wieku na Półwyspie Arabskim. Przyczyn rozwoju doświadczeń mistycznych można też upatrywać w czynnikach psychologicznych, niezależnych od samej religii. Nieodłączną cechą religijności, zwłaszcza $\mathrm{w}$ religiach monoteistycznych, jest ludzkie dążenie do indywidualizacji swoich kontaktów z Bogiem i doświadczeń związanych $\mathrm{z}$ uprawianiem Jego kultu. Idea dalekiego, transcendentnego Boga sprawia,

\footnotetext{
${ }^{1}$ Koran, thum. J. Bielawski, Warszawa 1986.
} 
że niektórzy pragną przekroczyć tę barierę, mieć w sobie cząstkę boskości. Inni zaś potrzebują namiastki Boga na ziemi, nie godzą się ze ścisłą granicą oddzielającą to, co ludzkie, od tego, co boskie. Pragną mieć w Bogu orędownika i pocieszyciela, ale też potrzebują doświadczenia boskości.

Dyskusja o tym, czy islam sprzyjał mistycyzmowi, czy też nie, wydaje się jałowa ze względu na fakt, że mistycyzm muzułmański rozwinął się $\mathrm{w}$ tej religii, i to na wielu płaszczyznach: od uproszczonych technik ascetycznych do wyrafinowanej filozofii mistycznej dla największych intelektualistów. Ponadto, islam szybko rozprzestrzenił się na wielkim terytorium kalifatu, od Chin po Hiszpanię, obejmując wiele różnych kultur, których elementy przenikały do islamu, o ile nie stały w sprzeczności z jego podstawowymi zasadami. Stosunek oficjalnego islamu do mistycyzmu był i jest zróżnicowany, zależał od czasu i miejsca: na niektórych obszarach w niektórych okresach uważano go za część kultury muzułmańskiej, kiedy indziej natomiast traktowano jako herezję, którą należy zwalczać. Jednak mimo jego zmiennych kolei losu, trudno dzisiaj zaprzeczyć, że mistycyzm jest nieodłączną częścią kultury islamu, bez której wizerunek tej cywilizacji byłby niepełny i ubogi.

\section{Początki mistycyzmu: Koran i hadisy}

Ponieważ nie sposób omówić wszystkich aspektów doświadczenia mistycznego, chciałabym się skoncentrować na początkach i tak zwanym okresie formatywnym mistycyzmu (IX-XI w.). Charakterystyczną jego cechą była działalność mistyków, którzy nie gromadzili się jeszcze w bractwa, czyli tariki, lecz działali indywidualnie. Właśnie oni wprowadzili do mistycyzmu podstawowe pojęcia, które w późniejszym okresie były dalej rozwijane i opracowywane przez wielkich sufich. Ponadto większość sufich z tego wczesnego okresu nie zostawiła po sobie żadnych pism, a ich poglądy są znane z późniejszych encyklopedii i słowników mistycyzmu, pisanych przez ich następców, którzy przytaczali wypowiedzi i opisywali poglądy prekursorów. Jest to jedyny materiał, jakim dysponujemy, zatem nie sposób go zweryfikować, jednak pokazuje to, jak sami sufi postrzegali swoje początki.

Arabska nazwa na określenie mistycyzmu brzmi sufizm (tasawwuf), a jej pochodzenie nie jest dzisiaj jasne ${ }^{2}$. Niewykluczone, że pochodzi od wyrazu

2 Jedną z pionierek badań nad mistycyzmem muzułmańskim była niemiecka badaczka Annemarie Schimmel (†2003), która znaczną część swojej bogatej spuścizny naukowej poświęciła różnym aspektom mistycyzmu. Por. na przykład: Mystical Dimensions of Islam, Chapel Hill 1975; The Triumphal Sun: A Study of the Works of Jalaloddinn Rumi, London; As Through a Veil: Mystical Poetry in Islam, New York 1982; Deciphering the Sings of God: A phenomenological Approach to Islam, Albany, 1994. 
suf, czyli 'wełna', z której szyto szorstkie wełniane ubrania dla pierwszych ascetów. Wskazywałoby to na istnienie wśród najwcześniejszych mistyków technik ascetycznych, zapożyczonych między innymi od anachoretów chrześcijańskich. Jednak islam zdaje się nie popierać ascezy i monastycyzmu (rahbanijja), Prorokowi przypisuje się hadis ${ }^{3}$ : „W islamie nie ma mnichów”.

Ascezę określa się terminem zuhd, który nie należy do pojęć koranicznych. Innym terminem, również nieobecnym w Koranie, jest nask, odnoszący się do wstrzemięźliwego życia eremity. Jak się często podkreśla, Koran nie zajmuje się szczególnie ascezą i pojawiają się tam jedynie wzmianki dotyczące niektórych aspektów ascezy: postu, czuwania czy użalania się nad sobą. Kontrastuje to $\mathrm{z}$ dość obfitym odnoszeniem się do czerpania z przyjemności życia seksualnego ${ }^{4}$, a także nakazem bogacenia się w celu wspierania misji Boga. Trudno w dzisiejszym stanie badań określić, jak wątki dotyczące technik ascetycznych trafiły do Koranu. Jeśli założyć, że jego rzeczywistym twórcą był Mahomet, oznaczałoby to, że musiał mieć informacje o technikach ascetycznych głównie z Syrii i Egiptu. Jednak jest bardzo wątpliwe, aby Mahomet kiedykolwiek dotarł na te tereny, co oznaczałoby, że te praktyki były obecne wśród chrześcijan na Półwyspie lub że krążyły o nich informacje ${ }^{5}$. Wiadomości o życiu i zachowaniu Mahometa są na ogół hagiograficzne, niepewne, i bardziej pokazują nam, jak chciały go postrzegać późniejsze pokolenia, niż mówią coś o nim samym. Zgodnie z tradycją jeszcze przed początkiem pierwszych objawień w 610 roku Mahomet miał zwyczaj spędzać miesiąc w roku na medytacjach na górze Hira w pobliżu Mekki ${ }^{6}$. Podobno uprawiał tahannus, niestety, nie wiemy dokładnie, co oznaczał ten niekoraniczny termin, być może uprawianie praktyk ascetycznych i ćwiczeń duchowych. Jednak nie należy przypisywać tej tradycji zbyt dużego znaczenia. Przedmuzułmańscy Arabowie byli wojownikami i koczownikami żyjącymi w surowych warunkach pustynnych, a późniejsze (IX w.) połączenie Mahometa z taką tradycją odzwierciedla przekonanie o wyjątkowości jego pozycji jako proroka wiary

${ }^{3}$ Hadisy cieszą się w islamie statusem świętego tekstu po Koranie. Są to zebrane w IX w. tradycje, zawierające słowa lub opis czynów proroka i jego najważniejszych towarzyszy. Muzułmanie wierzą w ich autentyczność, czyli że faktycznie pochodzą z pierwszej połowy VII w. i były zachowane w pamięci. Badacze zachodni traktują je w znacznej mierze jako teksty stworzone w IX w. na potrzeby rozwoju prawa.

${ }^{4}$ Chodziło tu o „dozwolony” seks z żonami lub niewolnicami. Wszelkie stosunki pozamałżeńskie określano mianem zina i karano zgodnie $\mathrm{z}$ Koranem karą stu batów. W hadisach tę karę zmieniono na kamienowanie.

${ }^{5}$ Chrześcijaństwo na Półwyspie Arabskim przed islamem, por. np. R. Hoyland, Arabia and the Arabs: From the Bronze Age to the Coming of Islam, London 2001; K. Borge. A Historical Survey of the Rise and Spread of Christianity in Arabia in the Firts Six Centuries AD, 2011, https://www. academia.edu/829636/Pre-Islamic_Christianity_in_Arabia [dostęp: 7.11.2019].

${ }^{6}$ K. Wagtendonk, Fasting in the Koran, Leiden 1968, s. 32-33. 
monoteistycznej, Boga jedynego - Allaha, nie zaś pokazuje rzeczywiste zwyczaje Arabów z tamtego okresu.

Wróćmy zatem do Koranu i praktyk ascetycznych, które zalecał. W surze 73 „Owinięty szatą” czytamy: „O ty, owinięty szatą! Czuwaj na modlitwie nocą, niewiele wypoczywając - pół nocy lub nieco mniej albo trochę więcej i recytuj wyraźnie Koran!” (73:1-4); „Zaprawdę twój Pan wie, że ty [Mahomet] i ci, którzy są z tobą, trwacie na modlitwie stojąc blisko dwie trzecie, połowę lub jedną trzecią nocy [...] Przeto recytujcie głośno to, co jest łatwe z Koranu!" (73:20). Czuwanie i recytacja to praktyki przejęte z chrześcijaństwa, jednak fakt, że znalazły się w Księdze traktowanej przez muzułmanów jako niezmiennie i doskonałe słowo samego Boga, je usankcjonował, tym bardziej że sunna, czyli tradycja, jest bardzo ważna dla muzułmanów, a postępowanie proroka to dla nich wzór do naśladowania.

W 48 surze „Zwycięstwo” o idących za Mahometem mówi się: „Widzisz ich kłaniających się wybijających pokłony, poszukujących łaski Boga i jego zadowolenia. Ich znamię jest na ich twarzach ${ }^{7}$ od śladów wybijania pokłonów” (K 48:29). W surze 76 „Człowiek” do samego proroka Bóg skierował słowa: „I nocą wybijaj mu pokłony! I długo nocą go wysławiaj!” (K 76:26) ${ }^{8}$. Inne fragmenty dotyczą postów, które były znane społeczności pustynnej i podobno były zalecane przez proroka jako antidotum na rozmaite choroby trapiące Arabów, co nie dziwi przy ówczesnym stanie medycyny na Półwyspie. Zgodnie z zaleceniami Koranu, Arabowie muszą pościć raz w roku w miesiącu zwanym ramadan, kiedy od wschodu do zachodu słońca powinni powstrzymywać się od jedzenia, picia, palenia, relacji seksualnych, jest to dozwolone dopiero po zmroku. Jednak w odwołaniach do ascetyzmu chodziło o dodatkowe posty, wynikające z pobożności i wstrzemięźliwości: „Ci, którzy się nawracają [...], ci, którzy poszczą” (K 9:112) i muzułmanki [...] Poszczący i poszczące [...]” (K 33:35); „da mu w zamian żony lepsze od was [...] Pobożne, przestrzegające postu" (K 66:5). Rdzeń,

7 Jednym z elementów modlitwy muzułmańskiej są tzw. sudżud, czyli pozycja, w której wierny, klęcząc, uderza czołem o ziemię. Niekiedy, aby uniknąć zetknięcia się w czasie wymagającej czystości rytualnej modlitwy z nieczystą ziemią, pokłony bito o specjalny krążek. Zgodnie z tradycją na czołach najbardziej gorliwych w modlitwie pozostawiał on ślad.

${ }^{8}$ Nie wdajemy się tutaj w subtelne i dotyczące już szczegółowych kwestii rozważania, czy te zalecenia miały dotyczyć jedynie Mahometa, czy też całej społeczności wierzących. Z punktu widzenia tych rozważań jest to nieistotne, gdyż Mahomet miał być przykładem do naśladowania. J. Baldick, Ascetism, w: Encyclopaedia of the Qur'ān, red. J. Dammen McAuliffe, t. I, Leiden 2001, s. 181-185.

9 Bielawski thumaczy to jako: „ci, którzy podróżują...”. Jednak, jak uważa Wagtendonk, termin saha jest tutaj użyty w kontekście poszczenia, tak jak w kolejnych przytoczonych przeze mnie wersetach, gdzie zresztą Bielawski, niekonsekwentnie, thumaczy go jako poszczenie. Por. K. Wagtendonk, Fasting in the Koran, s. 183. 
saha, odnoszący się tutaj do poszczenia, nigdy nie był używany w stosunku do postów w ramadanie, zatem musiało chodzić o inne, dodatkowe posty. Jednak wzmianki o dodatkowych postach są bardzo skąpe i nie pozwalają wysunąć twierdzenia, że Koran zalecał surowe, ascetyczne posty. Księga ta wspomina też krótko o płakaniu: „Oni padają na twarze płacząc, i to zwiększa ich pokorę" (K 18:109), jednak ponownie ta wzmianka jest zbyt lakoniczna, aby ją uznać za zachętę do techniki ascetycznej.

Poza przytoczonymi wersetami w Koranie można też znaleźć kilka innych fragmentów o podobnej treści: pobożni są opisani jako ci, którzy nie śpią nocą, lecz wybijają pokłony i recytują Koran. Jednak Koran nie jest zwartym traktatem, w którym treści wyłożono w sposób systematyczny i jasny. Jest w nim wiele wersetów ambiwalentnych (mutaszabihat) i sprzecznych. Zatem te fragmenty, aczkolwiek pokazują przyzwolenie na techniki łączone $\mathrm{z}$ ascezą, jednak są traktowane raczej jako część pobożności, a nie ascetyczna droga życia pociągająca za sobą odłączenie się od społeczności. Oczywisty w niektórych kulturach wyraz ascezy, czyli monastycyzm, w Koranie jest traktowany dość podejrzliwie. W surze „Żelazo” czytamy: „i złożyliśmy w serca tych, którzy poszli za Nim łagodność i miłosierdzie; i stan zakonny (rahbanijja) który oni wprowadzili - My im go nie przypisaliśmy - poszukując zadowolenia Boga; oni jednak nie zachowali go tak, jak powinni go byli zachować” (K 58:27). Ten werset jest niejasny i podlegał wielu interpretacjom, nie wynika $\mathrm{z}$ niego wyraźnie, czy i komu stan zakonny był przepisany, nie wiadomo też, do kogo dokładnie odnosi się stwierdzenie, że oni nie zachowali go tak, jak powinni. Jednak traktowano go jako potwierdzenie, że stan zakonny nie jest muzułmanom przepisany ani nawet zalecany. $\mathrm{W}$ innym miejscu mnisi są nawet potępieni: „Zaprawdę, wielu pośród uczonych w piśmie - rabinów i mnichów zjada nadmiernie majątki ludzi” (K 9:34).

Mimo to w muzułmańskiej sunnie zachowały się opowieści przypisujące zachowania ascetyczne osobom $z$ najbliższego otoczenia proroka, pierwszym nawróconym, którzy w swojej gorliwości modlili się i pościli, zaniedbując obowiązki wobec swoich żon. Kiedy małżonka jednego z towarzyszy, Usmana Ibn Mazuna, opowiedziała o tym prorokowi, ten miał odpowiedzieć, że Allah nie zachęca do życia mniszego (chodziło tu przede wszystkim o celibat). W wersjach Al-Buchariego i Ibn Madży prorok miał stwierdzić, że gdyby Bóg zezwolił na celibat, to pozwoliłby im na kastrację ${ }^{10}$.

Jak zatem wynika $\mathrm{z}$ tego krótkiego przedstawienia stosunku Koranu oraz hadisów, czyli podstaw życia religijnego muzułmanów, do tak ważnej w mistycyzmie ascezy, kwestia ta nie jest jednoznaczna. Nie sposób uznać, że święte teksty islamu zachęcają do pójścia drogą ascetyczną w celu zbliżenia się do

${ }^{10}$ Arabski Ibn Madża, Sunan, ks. 9, hadis 1920. 
Boga, a już na pewno nie traktują ascezy jako sposobu życia stosownego dla muzułmanów. Jednak nie można też jednoznacznie stwierdzić, że jej zabraniają, a zważywszy na fakt, że w dwuznacznych wersetach Koranu muzułmanie różnych odłamów teologicznych i nurtów intelektualnych doszukiwali się potwierdzenia swoich prawd, nie dziwi, że i zwolennicy mistycyzmu uznali, że Koran pochwala ich ścieżkę dojścia do Boga.

Można uznać, że w islamie jest tyle samo elementów sprzyjających rozwojowi mistycyzmu, jak i stanowiących dla niego przeszkodę. Nie ma jednak wątpliwości, że skąpe, lecz jednak obecne wzmianki o technikach ascetycznych przynajmniej dawały mistykom podstawę do myślenia, że Bóg nie jest im przeciwny. Natomiast jeśli chodzi o fikr, drugą istotną zasadę sufizmu, medytację, to Koran był jej impulsem i podstawą.

\section{Koran a fikr}

Jednak Koran miał zasadnicze znaczenie przy powstawaniu drugiej istotnej zasady sufizmu, którą jest fikr, czyli 'namysł', 'medytacja'. Bardzo często właśnie tekst koraniczny stawał się przedmiotem fikru, 'medytacji'. Od początku była to jedna z najpopularniejszych technik stosowanych przez sufich pojedynczych, a także w bractwach mistycznych. Fikr jest często przeciwstawiany innej technice mistycznej, zikrowi, czyli 'wypominaniu'. W zikrze mistyk koncentruje się na ciągłym wymienianiu jednego podmiotu, natomiast charakterystyczne dla fikru było uruchamianie całego ciągu skojarzeń, które mistyk przeżywał lub których doświadczał w związku z fragmentem, nad którym medytował. W Koranie istnieją fragmenty, które uważano za szczególnie przydatne do medytacji. Jest to na przykład fragment z sury „Światło”: „Bóg jest światłem niebios i ziemi. Jego światło jest podobne do niszy, w której jest lampa; lampa jest w szkle, a szkło jest jak gwiazda świecąca. Zapala się ona od drzewa błogosławionego - drzewa oliwnego, ani ze Wschodu, ani z Zachodu, którego oliwa prawie by świeciła, nawet gdyby nie dotknął jej ogień. Światło na świetle! Bóg prowadzi prostą drogą ku światłu kogo chce" (K 2435). Ten słynny, wielokrotnie przywoływany przez mistyków werset, nie tylko stał się przedmiotem medytacji, ale też te medytacje dały impuls do tworzenia traktatów mistycznych przedstawiających Boga jako światło. Do najsłynniejszych w mistycznej filozofii muzułmańskiej należy traktat Muhammada al-Ghazalego Miszkat al-anwar (Nisza świateł) ${ }^{11}$.

${ }^{11}$ Al-Ghazali, Miszkat al-anwar, red. Abd al-Aziz as-Sirwan, Alam al-kutub, Bejrut 1985; thum. J. Wronecka, Nisza światet, Warszawa 1990. Por. także K. Pachniak, Pojęcie światta w islamie. Mistyka światta w traktacie Nisza światet Al-Ghazalego, „Ethos”, 2017, nr 3(119), s. 136-153. 
Innym fragmentem Koranu, nad którym medytowano, był epizod opisany w surze „Podróż nocna”. Isra to właśnie owa podróż, podczas której, jak wierzą muzułmanie, Bóg w cudowny sposób przeniósł Mahometa $\mathrm{z}$ „Meczetu świętego do meczetu dalekiego", czyli z Mekki do Jerozolimy. Owa podróż odbyła się nocą, na grzbiecie cudownego stwora imieniem Al-Burak. W czasie podróży Al-Burak zatrzymał się na Wzgórzu Świątynnym i stamtąd Mahomet podobno wzniósł się do nieba na rozmowę z Bogiem. Ten epizod jest nazywany miradż. Podczas tej rozmowy Bóg i Mahomet ustalili liczbę dziennych modlitw obowiązujących muzułmanina. Isra i medytacja nad nią były uznawane przez mistyków za bardzo ważne, a szczególnie wzniesienie Mahometa prosto do Boga. Miradż to dla sufich symbol wędrówki, jaką odbywa się na drodze do Boga, symbol ostatecznego z nim połączenia ${ }^{12}$. Nic zatem dziwnego, że isra i miradż stanowiły przedmiot fikru, a często też bardziej złożonych traktatów mistycznych, np. Ibn al-Arabiego ${ }^{13}$.

$\mathrm{Z}$ medytacji nad miradżem zasłynął mistyk z wczesnego okresu islamu Al-Halladż (†922), który opisał swoje doświadczenia w Kitab at-tawasin ${ }^{14}$. Księga ta składa się z siedmiu rozdziałów zwanych tasin (zestawienie dwóch liter alfabetu arabskiego ta i sin), w których Al-Halladż swobodnie medytuje nad różnymi wątkami koranicznymi. W pierwszym rozdziale pojawia się odwołanie do wspomnianego wyżej wersetu o świetle, a Bóg jest przedstawiony jak najwyższe światło, doskonałe i niepoznawalne. Wszelka wiedza o Nim jest jedynie jak kropla wody w oceanie, nie jest w stanie oddać Jego doskonałości i majestatu, niedających się opisać ludzkimi słowami. W drugim rozdziale, opisując Boga jako byt poza wszelką rzeczywistością, Al-Halladż podaje porównanie ćmy i świecy: ćma jest jak mistyk, który zawsze jest przyciągany światłem świecy, aż w końcu w nim ginie. Tam również pojawia się odniesienie do miradżu Mahometa, który sprawił, że prorok posiadł wiedzę o rzeczywistości. Jednak, jak twierdzi mistyk, jedynie sam Bóg może wychwalać siebie w sposób, który jest Go godzien. W trzecim rozdziale Al-Halladż opisuje 40 przystanków (makamat), które mistyk przechodzi na swojej drodze

${ }^{12}$ Koran przekazuje na ten temat jedynie szczątkowe informacje. Bardziej rozbudowana wersja miradżu znajduje się w hadisach, np. u Al-Buchariego, narratorem jest Ibn Abbas. F. Colby, Narrating Muhammad's Night Journey: Tracing the Development of the Ibn 'Abbas Ascension Discourse, New York 2008.

${ }^{13}$ Ibn al-Arabi, Al-Isra ila makam al-asra, Bajrut 1977. Por. J.W. Morris, The Spiritual Ascension: Ibn 'Arabi and the Mi'raj, ,Journal of the American Oriental Society”, 107, 1987, s. 629-652, 108, 1988, s. 63-77.

${ }_{14}$ Al-Halladż, Kitab al-tawasin, red. L. Massignon, Paris 1913. Na temat tego słynnego mistyka powstała dość obfita literatura. Klasyczna pozycja to L. Massignon, La Passion de Husayn Ibn Mansûr Hallâj : martyr mystique de l'Islam, exécuté à Bagdad le 26 mars 922 : étude d'histoire religieuse, Paris 1975 (istnieją też liczne inne wydania). Najnowsza pozycja to: S. El-Jaichi, Early Philosophical Sufism: The Neoplatonic Thought of Husayn ibn Manșūr al-Hallāğ, New York 2018. 
duchowej, aby zdobyć wiedzę o rzeczywistości. Ostatni przystanek, przed dosięgnięciem absolutu, nazywa się bidaja ('początek'). Ostatnia stacja jest osiągalna jedynie dla ludzi o spokojnym sercu i czystych intencjach. Poprzez nią osiąga się szczególną iluminację (tadżalli chass). Al-Halladż utożsamia się również z krzewem gorejącym, przez który przemawiał do Mojżesza Bóg (,Oto zobaczył on ogień i powiedział do swojej rodziny: Pozostańcie! Zauważyłem ogień [...]. A kiedy podszedł do niego, usłyszał zawołanie: O Mojżeszu! Zaprawdę, ja jestem twoim Panem! Zdejm swoje sandały! Jesteś w świętej dolinie Tuwa!” (K 20:10-23, także K 27:7-8; 28:29-3). Szczególne zainteresowanie wzbudza fragment, w którym Al-Halladż medytuje nad Iblisem (Szatanem), który został pokarany swoją pozycją za nieposłuszeństwo wobec Boga: odmówił złożenia pokłonu człowiekowi (K 7:11-18; 15:31-42). Mojżesz spotka Iblisa na górze Synaj i pyta go o powody jego decyzji. Iblis wyjaśnia mu, że ze strony Boga nie był rozkaz, lecz test, i zmiana jego wyglądu o niczym nie świadczy, gdyż nie dotyka to w żaden sposób jego duchowego wizerunku. Dodaje, że pamięta Boga, a Bóg pamięta jego, zatem ich pamięć jest wspólna. Iblis przedstawia się jako ten, który połączył się Bogiem, został przez Niego doświadczony, celowo wprowadzony w stan upokorzenia: Bóg go porzucił z powodu ich zjednoczenia, odciął się do niego z powodu jego pragnienia bycia z Nim (Bogiem). Następnie sam Al-Halladż, powołując się na przykład Iblisa, wygłasza swoje słynne stwierdzenie: „Ja jestem znakiem (tadżalli) Boga i ja jestem Jego prawdą (Ana al-hakk). Dzieje się tak dlatego, że nieustannie medytuję nad prawdą"15. Ponieważ hakk to jeden z Bożych atrybutów (sifat), takie stwierdzenie uznano za przypisywanie sobie przez Al-Halladża cech boskich ${ }^{16}$.

Fikr jest często przeciwstawiany zikrowi, czyli wypominaniu, jednej z podstawowych technik mistycznych polegającej na wielogodzinnej recytacji imienia Boga, jednej z jego cech lub krótkich tekstów np. Huwwa hajj (On jest żywy). Tym długim recytacjom towarzyszy muzyka oraz ruchy ciała i techniki oddechowe, co razem służy osiągnięciu stanów transowych czy też - używając języka mistyków - zbliżeniu się do Boga. Zdaniem niektórych mistyków, w tym Al-Halladża, zikr i fikr powinny iść w parze, jednak fikr jest metodą dyskursywną, głęboką i intelektualną, podczas gdy zikr ma w sobie elementy bierne. W Kitab at-tawasin twierdzi on, że $f i k r$, 'czysty namysł', nie wymaga już zikru. Medytacja prowadzi adepta prosto ku Bożemu majestatowi, oferuje mu możliwość doświadczenia prawd transcendentnych, podczas gdy zirk ${ }^{17}$,

15 Pozycja Iblisa w mistycyzmie muzułmańskim: P. Awn, Satan's Tragedy and Redemption. Iblīs in Sufi Psychology, Leiden 1983.

16 П.В. Башарин, Концеепиия «ана-Хакк» ал-Халладжа и ее отражение в последующей суфийской традиции, „Рax Islamica”, 1, 2008, s. 46-62.

${ }^{17}$ Kitab at-tawasin, s. 46. 
'recytacja', przez czysto mechaniczne zaangażowanie organów zmysłowych najpierw pomaga w koncentracji intelektualnej, a potem dzięki niemu mistyk osiąga kolejne stany (ahwal) lub też przystanki (makamat) na swojej drodze (tarika) ku Bogu.

Al-Halladż był postacią szczególną w historii muzułmańskiego mistycyzmu, gdyż jego życie zakończyło się tragicznie: za swoje poglądy został skazany na okrutną śmierć. Tradycja przypisuje mu radość z egzekucji, gdyż uznając się za ukochanego (aszik) Boga, uważał też, że miłość realizuje się poprzez cierpienie. $Z$ takiego przekonania może wynikać jego interpretacja postaci Iblisa: $\mathrm{w}$ islamie jest on potępiony, u Al-Halladża jest postacią tragiczną, kocha Boga tak silnie, że zgadza się dla Niego na największe poniżenie, oszpecenie fizyczne i duchowe, odtrącenie. Odmowa przez Iblisa złożenia pokłonu człowiekowi wynika ze ścisłego monoteizmu, niechęci do uznania, że istnieje ktokolwiek poza Bogiem, któremu należałoby złożyć pokłon. W radykalnej interpretacji Al-Halladża mistyk przyjmuje na siebie to, co złe, z czystej Bożej miłości, doświadcza upokorzenia, w którym zamyka się jego miłość do Najwyższego. Wielka znawczyni mistycyzmu muzułmańskiego, A. Schimmel, skłania się ku interpretacji, że w ten sposób Al-Halladż doświadczał ukrytej tajemnej miłości do Boga, która nie miała być ujawniania publicznie ${ }^{18}$. Niewykluczone, że Al-Halladż pragnął śmierci, traktując ją jako ostatni makamat na ścieżce mistycznej, ostatni krok oddzielający go od Boga.

\section{Okres mistyków pojedynczych}

W okresie mistyków pojedynczych, czyli IX-XI w. w islamie pojawia się szczególnie wiele postaci mistyków i mistyczek, którzy jednak nie tworzą grup, lecz praktykują indywidualnie, opracowując pojęcia mistyczne, jak wspomniany wyżej Al-Halladż ${ }^{19}$. W swoich koncepcjach starają się wyjaśnić wewnętrzny paradoks duchowy ludzkiej egzystencji: uznanie jedności Boga i jedności z Bogiem oraz oczywiste Jego oddzielenie od wszelkiego stworzenia $^{20}$. Podnoszą także inną sprzeczność: Jak pogodzić absolutną Bożą dobroć oraz zło istniejące na świecie? Jednak największego znaczenia w tym okresie nabiera inne pojęcie: miłości mistyka do Boga, traktowanie Go jak kochanka, a stanu najwyższego uniesienia jak miłosnego zbliżenia. Wprowadzenie pojęcia $h u b b$, 'miłości', przypisuje się kobiecie, jednej z pierwszych mistyczek

\footnotetext{
${ }^{18}$ A. Schimmel, Mystical Dimension, s. 73.

19 Na temat wczesnego okresu rozwoju mistycyzmu: A. Karamustafa, Sufism: The Formative Period, Edinburgh 2007.

${ }^{20}$ J. Renard, Knowledge of God in Classical Sufism: Foundations of Islamic Mystical Theology, New York 2004.
} 
z wczesnego okresu mistyków pojedynczych, imieniem Rabi'a al-Adawijja (†801). Jej tożsamość historyczna nie bywa kwestionowana, jednak jej życie obrosło tak wieloma mitami i legendami, że trudno z niego wyłuskać prawdę historyczną ${ }^{21}$. Należy uznać, że nawet owe mity są znaczące dla postrzegania postaci wyjątkowej, również z racji swojej płci. Wedle tradycji Rabi’a była jedną z trzech „mistyczek z Basry”, żyjących w tamtym okresie ${ }^{22}$. Słynęła ze skrajnego ascetyzmu, a Al-Dżahiz, słynny intelektualista tamtych czasów, cytuje jej słowa, że wstydziłaby się prosić o dobra tego świata od Boga, do którego one należą, a tym bardziej nie mogłaby prosić o pomoc ludzi, do których one nie należąa ${ }^{23}$. Niezależnie od prawdziwości tej opowieści, Rabi’a była jedną z prekursorek fakr, 'ubóstwa', jednej z zasad wczesnego mistycyzmu, uważanej za niezbędną na drodze do Najwyższego.

Do naszych czasów zachowała się garstka fragmentów mistycznej poezji stworzonej przez Rabi'ę, które zostały przekazane przez późniejszych mistyków. Rabi’a najbardziej zasłynęła ze swoich nauk o miłości do Boga (hubb, mahabba). Powtarzała, że Bóg jest towarzyszem jej serca, a Ukochany jej serca jest zarazem gościem jej duszy. Wyjaśniała, że miłość do Boga zawładnęła nią do tego stopnia, że w jej sercu nie ma już miejsca na miłość do innych ludzi, nawet do Proroka. Jej miłość do Boga jest pełna i egoistyczna: są tylko we dwoje, ona i Bóg. Al-Ghazali (†1111), sam słynny intelektualista i mistyk, napisał w Ihja ulum ad-din (Ożywienie nauk religii), że zdaniem Rabi'i, warunkiem poznania Boga w przyszłym świecie jest poznanie Go najpierw w tym świecie na drodze mistycznej i jeśli ktoś nie dążył do Niego w świecie doczesnym, nie zdoła się też do Niego zbliżyć w przyszłym życiu ${ }^{24}$. Rabi'a podobno zupełnie lekceważyła sprawy tego świata, uważając, że nie są one ważne, gdyż jedynym celem mistyka jest szukanie towarzystwa Boga, który jest wieczny.

Pojęcia hubb lub iszk, miłości odczuwanej przez mistyka do Boga, miały się stać kluczowymi dla mistyków muzułmańskich we wszystkich okresach $^{25}$. Znaczenia nabrał odcień szauk, 'pożądania', jakie mistyk odczuwa do Boga, przedstawiając Go jako swojego Ukochanego lub Ukochaną. Miłość mistyka do Boga przestała być zwykłym wyrazem wdzięczności za Jego łaski, które odczuwać powinien każdy wierzący muzułmanin. Taka miłość staje się

${ }^{21}$ Najnowsza i najpełniejsza analiza tej postaci: R.E. Cornell, Rabi 'a from Narrative to Myth, London 2019 (pierwsze wydanie 1998).

${ }^{22}$ Pozostałe to Mu'aza al-Adawijja, żona ascety Al-Kajsa al-Anbariego, oraz Umm ad-Darna. Ch. Pellat, Le milieu basrien et la formation de Ğăhiz, Paris 1953, s. 104 i dalsze, R.E. Cornell, Rabi'a...

${ }^{23}$ Al-Dżahiz, Kitab al-hajawan, t. V, s. 589.

${ }^{24}$ Al-Ghazali, Ihja ulum ad-din, t. IV, Kair, br., s. 269.

${ }^{25}$ J.E.B. Lubmard, From hubb to 'ishq: the Development of Love in Early Sufism, „Journal of Islamic Studies”, 18, 3, 2007, s. 345-385. 
absolutną koniecznością, dążącą do wzajemności i połączenia. Uznać można, że właśnie w tym wczesnym okresie mistycyzmu u Rabi’i al-Adawijji oraz Al-Halladża pojęcie miłości do Boga jest wyrażane najintensywniej, ma najwięcej konotacji fizycznych. W późniejszym mistycyzmie filozoficznym, nawet $u$ wielkiego dwunastowiecznego mistyka Ibn al-Arabiego z muzułmańskiej Hiszpanii, miłość traci tak silne skojarzenia fizyczne i zaczyna oznaczać podziw dla wielkości i doskonałości Bożej.

Innym mistykiem z wczesnego okresu, którego nazwisko łączy się z ważnymi pojęciami mistycznymi był $\mathrm{Zu}$ an-Nun Misri (†862?), postać w muzułmańskim mistycyzmie szczególna, gdyż w słownikach biograficznych opisuje się jego związki z alchemią i magią, które były zakazane $\mathrm{w}$ ortodoksyjnym islamie. Niewykluczone, że znał język syriacki i był spadkobiercą Empedoklesa oraz tradycji hermetycznych ${ }^{26}$. Przypisuje mu się bardzo dużo listów, modlitw, kazań itp., które, co częste w przypadku mistyków z wczesnego okresu, zostały przytoczone w późniejszych arabskich dziełach i wymagają jeszcze dalszej analizy ${ }^{27}$. Najprawdopodobniej on właśnie był pierwszym mistykiem, który wprowadził tak ważne pojęcia teoretyczne jak marifa ('gnoza') ${ }^{28}$, makamat ('stacje') oraz ahwal ('stany'), które mistyk przeżywa i przechodzi na drodze do Boga. Ponadto wśród przypisywanych mu wypowiedzi pojawiają się takie pojęcia jak sidk ('prawda') oraz ichlas ('szczerość'). Bóg jest ich źródłem, jest ich ucieleśnieniem, a mistyk ma się starać do nich dążyć. Podobnie jak inni mistycy z tego okresu, Al-Misri przykładał wielkie znaczenie do fakr, czyli 'ubóstwa', twierdząc, że ubodzy mistycy (fukara al-arifin) są panami przyszłego świata, ich trud zostanie nagrodzony ${ }^{29}$. Kładzie też nacisk na skromność ( haja) i upokorzenie (tawadu), nieprzywiązywanie się do rzeczy tego świata, gdyż są one jedynie ułudą ${ }^{30}$. Osoba posiadająca prawdziwą wiedzą religijną ( $\mathrm{ilm}$ ) nie powinna interesować się tym światem ${ }^{31}$. Al-Misariemu przypisuje się stwierdzenie, że mądrość (ilm) nie idzie w parze z pełnym żołądkiem (la taskunu al-hikma ma 'ida muli'at ta 'aman) ${ }^{32}$. Wysoką

${ }^{26}$ P. Kingsley, Ancient Philosophy, Mystery and Magic: Empedocles and Pythagorean Tradition, Oxford 1995, s. 389-390.

${ }^{27}$ Największy zbior jego wypowiedzi cytuje Abu Nu'ajm al-Isfahani (†1038), uczony pochodzenia perskiego. Jest domniemanym autorem dziesięciotomowego dzieła Hilijat al-awlija wa tabakat al-asfija, podstawowej pracy o rozwoju wczesnego sufizmu muzułmańskiego, w której zamieścił biografie 650 mistyków i ich teksty. Edycję przygotowano w Dar al-kutub al-ilmijja, Bejrut 1988. Informacje o Al-Misrim, t. IX, s. 331-395.

${ }^{28}$ R. Shah-Kazemi, The Notion and Significance of Ma 'rifa in Sufism, „Islamic Studies”, 13/2, 2002, s. 155-181.

${ }^{29}$ Al-Kuszajri, Risala al-Kuszajrijja fi ilm at-tasawwuf, Alam al-kutub, Al-Kahira 2004, s. 476.

${ }^{30}$ M. Ebstein, Dַu l-Nūn Miṣrī and Early Islamic Mysticism, „Arabica”, 61, 2014, s. 559-612.

${ }^{31}$ Al-Isfahani, Hilijat al-awlija wa tabakat al-asfija, t. IX, Dar al-kutub al-ilmijja, Bejrut 1988, s. 335 .

${ }^{32}$ Al-Kuszajri, Risala al-Kuszajrijja, s. 416. 
pozycję w jego naukach zajmowało też zalecenie bezsenności (sahar), aby w tym czasie oddawać się modlitwom oraz zikrowi ${ }^{33}$.

Mistycy z wczesnego okresu nie obawiali się śmierci. Skrajna asceza i odrzucenie wszystkich przyjemności życia (szahwa) sprawiały, że o śmierci myśleli jako o wyzwoleniu od ziemskich kajdan, traktując ją jak przekroczenie bariery oddzielającej ich od Boga. Nazywało się to upodobaniem śmierci (istidlal al-maut $)^{34}$. Śmierć w islamie jest traktowana jako akt nieunikniony, którego nie należy się obawiać, gdyż zbliża człowieka do Boga. Medytowanie nad nią było powszechne wśród mistyków od wczesnego okresu islamu ${ }^{35}$.

Za największą przeszkodę na drodze do zlania się z Bogiem w jedno uznawano, paradoksalnie, niektóre elementy duszy, a właściwie ego mistyka ${ }^{36}$. Im dalej posuwał się on w swoich doświadczeniach mistycznych, im więcej makamat na drodze do Boga pokonywał, tym większą dumę to w nim rodziło, a to okazywało się pułapką. Zu an-Nun al-Misri uznawał duszę (nafs) za zasłonę (hidżab) oddzielającą mistyka od Boga ${ }^{37}$. Mudżahada, czyli walka z cielesnym ego mistyka to jeden z najważniejszych obowiązków sufich. Mistyk musi uznać niższość (zull) własnej duszy. Można uznać, że wszystkie praktyki ascetyczne, posty, bezsenność, odrzucenie dóbr świata - wszystkie te elementy stanowią część tej walki. Jej celem jest oczyszczenie duszy mistyka, odrzucenie $\mathrm{z}$ niej zbędnego balastu i uczynienie jej godną do stanięcia w obliczu Boga. Aby kontrolować swoją duszę, mistyk musi nieustannie ją oceniać i rozliczać się z nią (muhasaba al-nafs).

Pojęcie muhasaba, posunięte w skrajnych przypadkach aż do swoistego „samobiczowania” się intelektualnego, nieustannego rozważania, co uczyniło się źle, we wczesnym okresie mistycyzmu łączy się z mistykiem z Bagdadu, Harisem al-Basrim (†857), który jest bardziej znany pod swoim przydomkiem Al-Muhasibi. Uznawał on, że bardzo często ubóstwo, obowiązkowe dla mistyka, i zewnętrzna asceza mogą być jedynie pozorne, aby odwracać uwagę od niegodnych, ukrytych intencji ego, gdyż grzeszne czyny są często definiowane nie przez swój wyraz obiektywny, lecz subiektywną postawę grzesznika. Mogą się zatem ukrywać w najgłębszych warstwach jego ego, niewidoczne dla ludzi, lecz oczywiste dla wszechwiedzącego Boga. Do kontrolowania pokus cielesnych konieczny jest rozum (akl), nie wystarczy tutaj

${ }^{33}$ Al-Ghazali, Ihja, t. IV, s. 640; Al-Isfahani, Hilijat ..., s. 362.

34 Al-Isfahani, Hilijat..., s. 341-42.

${ }^{35} \mathrm{Na}$ temat śmierci w interpretacji mistyków z późniejszego okresu, por. A.O. Fahm, A Brief Analysis on the Meditation on Death in Sufism. With Reference to Al-Ghazālī and al-Rūmī, „The International Journal of Religion and Spirituality in Society", 4, 3, 2014, s. 6-14.

${ }^{36}$ S. Sviri, The Self and its Transformation in Sufism, w: Self and Self-Transormation in the History of Religions, red. D. Shulman, G.G. Stroumsa, Oxford 2002, s. 195-2015.

${ }_{37}$ Al-Isfahani, Hilijat..., s. 352; W.C. Chittick, The Perfect Man as the Prototype of the Self in the Sufism of Jāmī, „Studia Islamica”, 49, 1979, s. 135-157. 
sama duchowość i irracjonalność. Podkreślenie roli intelektu było charakterystyczną cechą koncepcji Al-Muhasibiego, gdyż na ogół mistycy muzułmańscy, opisując drogę do Boga, kładli nacisk na duchowość i wyłączenie przeżycia mistycznego z kategorii rozumowych.

Al-Muhasibi eksponował także proces tazkijja an-nafs, czyli 'oczyszczenia ego' ${ }^{38}$. Polegał on na przeprowadzeniu ego od żałosnego stanu koncentracji na cielesności i pokusach, aby osiągnąć stopień czystości oraz poddania się Bogu. Bez tego procesu, obejmującego różne etapy duchowe, nie było możliwe zbliżenie się do Boga. Tazkijja jest terminem koranicznym, używanym w nim bardzo często, na przykład w surze Al-Bakara (Krowa), At-Tauba (Skrucha) czy Hud. Człowiek, aby osiągnąć wieczne szczęście, musi oczyścić swoją duszę z wszystkich złych cech (achlak mazmuma), a następnie przyjąć cnoty moralne i etyczne. Zdaniem Al-Muhasibiego, człowiek musi uznać, że poszukiwanie duchowe jest ważniejsze niż wszystko, co można osiągnąć na tym świecie. Po zakończeniu tego procesu mistyk osiąga stan ego nazywany w Koranie nasf mutma 'inna, 'duszą uspokojoną': „O ty, duszo uspokojona, powróć do twego Pana, zadowolona i z upodobaniem przyjęta!” (K 89:27-28) ${ }^{39}$.

Abu Nasr as-Sarradż (†988) wymienia w Kitab al-luma fi-at-tasawwuf $f^{40}$ siedem makamat, które mistyk musi przebyć w celu oczyszczenia swojego ego. Pierwszy etap zaczyna się od spłynięcia do duszy światła wiedzy (nur al-marifa), które pozwala jej uznać swoją grzeszność. Głównym elementem tego etapu jest tauba, skrucha, podczas której mistyk żałuje za popełnione złe czyny i powraca do stanu pierwotnej czystości duszy. W następnej fazie, wara, czyli 'powstrzymywania się', mistyk odrzuca wszystko, co jest przeszkodą na drodze do Boga. Asceza, czyli zuhd, jest przez As-Sarradża określana jako całkowita pustka serca, pozbycie się z niego wszelkich sentymentów i uczuć oprócz tych do Boga. Dusza powinna pozostać obojętna, a nawet zimna (barida) na wszelkie sprawy tego świata, powinna działać jedynie dla przyjemności Boga. Czwarty makamat, fakr, czyli 'ubóstwo' dotyczy spraw fizycznych i duchowych. W przypadku ubóstwa duchowego chodzi o to, że dusze wypełnia jedynie pragnienie Boga i dążenie do Niego, z lekceważeniem dla innych spraw. Sabr, czyli 'cierpliwość', oznacza w interpretacji As-Sarradża znoszenie wszystkich przeciwności losu, które w znacznej mierze mistyk przygotowuje sobie sam, wystawiając się na cierpienia i odrzucając wszystkie wygody tego świata. Szósty etap to zaufanie, tawakkul, kiedy mistyk uznaje,

${ }^{38}$ G. Picken, Spiritual Purification in Islam. The Life and Works of al-Muhāsibī, London-New York 2011.

39 Al-Muhasibi, Mu'atabat an-nafs, red. M. Ata, Al-Kahira, 2015, s. 30-90 passim.

${ }^{40}$ As-Sarradż, Kitab al-luma fi-at-tasawwuf, red. R. Nicholson, Leiden 1914, arabski tekst: http://www.sufi.ir/books/download/farsi/sarraj-toosi/al-luma-fi-tasavof-en-ar.pdf [dostęp: 7.11.2019]. 
że wszystko na świecie pochodzi od Boga, On jest źródłem wszystkiego. Podstawa tawakkul jest pełne uznawanie tauhidu, 'Bożej jedności i jedyności'. Dopiero kiedy człowiek zaakceptuje wszystko, co gotuje mu los, a co wynika z Bożej woli i przeznaczenia, kiedy odrzuci ten świat, osiągnie zadowolenie, czyli rida. Polega ono na pełnym podporządkowaniu się Bogu i wypełnianiu Jego woli. W stanie zadowolenia nie odczuwa się niczego poza przyjemnością obcowania z Bogiem, znika wszelki fizyczny i psychiczny ból istnienia.

Dla mistyka rzeczywistością nie jest ten świat, lecz Bóg, Jego wola, prawdziwa wiedza, wieczne światło i najwyższe piękno i dobro. Świat ziemski $\mathrm{w}$ zestawieniu z tymi przymiotami jest jedynie iluzją, ucieleśnieniem nierzeczywistości i niebytu. Oznacza to, że dopiero zbliżając się do Boga mistyk zaczyna żyć naprawdę. Świat rozumiany w sensie fenomenologicznym to jedynie mazhar, 'manifestacja jedynego rzeczywistego świata, świata prawdy Bożej'.

\section{Cel ścieżki - stan fana}

$\mathrm{Z}$ punktu widzenia zasad ortodoksyjnego islamu najwięcej kontrowersji budziła nie sama chęć zbliżenia się mistyka do Boga, a będący celem ekstazy mistycznej ostatni makamat na drodze (tarika) do niego: moment połączenia się mistyka z Bogiem, stan, w którym na jedną chwilę znika ,ja” człowieka, a wypełnia je ,ja" Boga. Niektórzy badacze w tym ekstatycznym stanie dostrzegają wpływy kultury indyjskiej, co jednak pozostaje poza problematyką tego artykułu ${ }^{41}$. Człowiek na ziemi jest mikrokosmosem, w którym odzwierciedlają się Boże atrybuty, jednak w niedoskonałej, ziemskiej for$\mathrm{mie}^{42}$. Człowiek może uniknąc tego niedoskonałego życia tylko w jeden sposób - odcinając się od świata. Pozostawało jednak otwarte pytanie, nurtujące nie tylko mistyków, ale również muzułmańskich filozofów i teologów bez inklinacji mistycznych: Na ile na to odcięcie się od świata i zbliżenie do Boga ma wpływ sam człowiek, a na ile wynika to z samej Bożej woli, która determinuje życie człowieka? Wydaje się, że od IX wieku mistycy zaczęli odchodzić od takiego pojmowania na rzecz sugerowania, że Bóg i człowiek mogą stać się jednym w stanie najwyższego połączenia, fana.

${ }^{41}$ Pisze o tym R.C. Zaehner, Hindu and Muslim Mysticism, London 1960, jednak pozycja ta jest często krytykowana; P. Basharin, The Problem of Indian Influence on Early Sufism, Proceedings of Three Day International Seminar on Cultural Exchange between India, Iran, Turkey, Afghanistan and Central Asia: Contrubution of Scholars, Sufis and Poets, New Dehli 2016, s. 41-52.

${ }^{42}$ S.M. Khamenei, „Man's Creativity/Vicegerency” in Islamic Philosophy and Mysticism, w: Islamic Philosophy and Occidental Phenomenology on the Perennial Issue of Microcosm and Macrocosm, red. A.T. Tymieniecka, Zurich 2019, s. 149-159. 
Nie wiemy dokładnie, który z mistyków jako pierwszy wprowadził koncepcję tej unio mystica, będącą celem życia sufiego. Wspomina się o Abu Sa'idzie Charrazie, chociaż często przypisuje się ją Abu Jazidowi al-Bistamiemiu, o którym niżej. Termin fana wymienia się razem z określeniem baka, oznaczającym 'pozostanie', 'przetrwanie'. Łącznie oznaczają one, że mistyk odchodzi z tego świata, aby stać się częścią Bożej substancji. W niektórych interpretacjach fana oznacza annihilację Bożego „ego” mistyka i zniknięcie jego niedoskonałych atrybutów, które na moment najwyższej ekstazy zostają zastąpione doskonałymi przymiotami Boga. Koniecznym warunkiem doznania tego stanu jest wcześniejsze porzucenie wszystkiego, co łączy się z tym światem: jego przyjemności i smutków, cielesności, niższych władz duszy, gdyż są one uznawane za przeszkody na drodze do Boga. Stan fana jest to stan mistycznego uniesienia, mistycznej wizji, w której mistyk uświadamia sobie, na czym polega tauhid, Boża jedność i jedyność. Mistyk podczas tego stanu uświadamia sobie, że jego ziemska egzystencja jest niczym w porównaniu z połączeniem się z Bogiem. Jednak jego osiągnięcie wymaga porzucenia własnego ego oraz stanu samoświadomości, mistyk musi na chwilę trwać w stanie niebytu, rozpływa się w Bożym tauhidzie. Stan niebytu osiągany przez mistyka przywodzi na myśl stan pierwotnej preegzystencji, w jakim ludzkość trwała, zanim została stworzona przez Boga ${ }^{43}$. Przebywając w stanie fana, mistyk przechodzi cykl, w obecności Boga powraca do swojego stanu wyjściowego, w którym stworzył go Bóg. Ów stan niebycia jest dla niego w aktualnej chwili jedynym możliwym sposobem istnienia. Chcąc wzmocnić autorytet tych pojęć, mistycy przywoływali werset koraniczny, w którym występują one razem: „Wszystko, co jest na niej [ziemi] przeminie (fanin), a pozostanie (jabka) oblicze twego Pana, pełne majestatu i godne czci" (K 55:26-27).

Domniemany prekursor stanu fana, Abu Sa'id al-Charraz (†899) jest w mistycznej encyklopedii As-Sulamiego nazywany awwal man takallama $f i$ ilm al-fana wa-al-baka ('pierwszym, który mówił o stanie fana i baka' )44. Był on mistykiem ze szkoły bagdadzkiej i w tym mieście urodził się najprawdopodobniej na początku IX wieku. Był związany z bagdadzką szkołą mistycyzmu, do której należał też $\mathrm{Zu}$ an-Nun al-Misri. Bardzo dużo podróżował, co - być może - wynikało $\mathrm{z}$ chęci uniknięcia prześladowań za ekstrawaganckie poglądy. Wilfred Madelung sugeruje, że Al-Charraz starał się w swoich

${ }^{43} \mathrm{Na}$ temat stanu pierwotnej preegzystencji (wakfa) wspominali $\mathrm{Zu}$ an-Nun al-Misri, por. Al-Isfahani, Hilijat..., s. 367, oraz Al-Dżunajd. Por. G. Bowering, The Mystical Vision of Existence in Classical Islam, Berlin, 1980.

${ }^{44}$ Ali al-Hudżwiri, Kaszf al-mahdżub, red. W. Zukowski, Tehran, 1957, s. 180; Abu Abd al-Rahman as-Sulami, Tabakat as-sufijja, red. N. Szurajba, Dar al-kutub al-ilmijja, Al-Kahira 1952, s. 228. Na jego temat, por. N. Saab, Mystical Language and Theory of Sufi Writings in the Sufi Writings of Kharrāz, Yale 2004. 
koncepcjach wesprzeć typowe dla mistycyzmu poglądy muzułmańskim szariatem, prawem religijnym, twierdząc na przykład, że wszystkie ezoteryczne doktryny muszą być zgodne z jawną (zahir) naturą prawa religijnego ${ }^{45}$. Idea stanu fana pojawiała się już u wcześniejszych mistyków, Al-Charraz był jednak prawdopodobnie pierwszym, który uczynił z niej fundament swojego nauczania. Być może nasze przekonanie o jego pierwszeństwie wynika też z faktu, że w przeciwieństwie do piśmiennictwa innych mistyków z wczesnego okresu pewne jego dzieła zachowały się do naszych czasów ${ }^{46}$. $Z$ pewnością idea fana zaczęła być częściej opisywana po 922 roku, czyli egzekucji w Bagdadzie Al-Halladża. Jednym z powodów egzekucji było jego wspomniane już wyżej twierdzenie Ana al-hakk („Ja jestem prawdą”), które uznano za kwestionowanie zasady tauhidu i zrównanie się człowieka z Bogiem. Środowisko bagdadzkich mistyków zaczęło wyjaśniać, na czym polega stan fana, aby chociaż po śmierci uwolnić Al-Halladża od oskarżeń.

Dla Al-Charraza fana, 'annihilacja świadomości człowieka', oznaczała utratę w chwili ekstazy ludzkich atrybutów i w zamian uzyskanie atrybutów Boga, mistyk jest stworzony z Boga (at-tachalluk bi-achlak Allah) i pozostaje w Bogu (baka bi-Allah) ${ }^{47}$. Boża jedność i jedyność wypełnia ,ja” mistyka, co ujawnia się w stwierdzeniach, że stare ,ja” (ana) stało się niczym (la), a nowe ,ja" wyraża się twierdzeniem ,Ja nie jestem mną". Al-Bistami twierdził, że zrzucił własną skórę jak wąż, ujrzał swoją własną esencję (zat) i stał się Bogiem (Ana huwwa), dosłownie „Ja jestem Nim”48. Fana nie jest zwykłym stanem, w którym ludzkie istnienie jedynie ustaje, lecz nabyciem doskonalszej, pełniejszej osobowości, wypełnionej atrybutami Boga. Baka, 'pozostanie', oznacza przetrwanie w tej nowej, udoskonalonej osobowości. Nawet gdy mistyk powraca po stanie ekstazy do swojego stanu normalnego, ma już zawsze poczucie niedoskonałości tego świata.

Abu Jazid al-Bistami (al-Bastami, $† 848 / 9$ ), to muzułmański mistyk perskiego pochodzenia, którego jego kontynuatorzy określali zaszczytnym tytułem sultan al-arifin ('władca gnostyków'). Uważa się go za jednego z twórców szkoły mistyków „upojonych” (sukr) Bogiem, których zachowania posuwały się aż do szatahat ('ekstrawagancji'). Podobnie jak wielu innych mistyków z wczesnego okresu, Al-Bistami nie zostawił po sobie źródeł pisanych, niewykluczone, że niczego nie napisał, a nasza wiedza o jego poglądach pochodzi

45 W. Madelung, Al-Kharrāz, Encyclopedia of Islam 2, Leiden, 2004.

4646 Al-Charraz, Rasa'il, red. K. Samarra'i, Bagdad 1967.

47 S. Sarrabi-Zadeh, Practical Mysticism in Islam and Christianity. A Comparative Study of Jalal ad-Din Rumi and Meister Eckhart, London-New York 2016, s. 182-187.

${ }^{48}$ Wypowiedzi Al-Bistamiego, zwane szatahat, ekstrawagancjami, nie zachowały się bezpośrednio. Zebrał je mistyk żyjący dwa stulecia poźniej As-Sahladżi (†1084), Kitab an-nur min kalimat Abi Tajfur, red. A. Badawi, Dar alkutub al-ilmijja, Al-Kahira 1949, s. 77. 
z późniejszych muzułmańskich encyklopedii mistycyzmu ${ }^{49}$. Przypisuje mu się skrajny ascetyzm oraz praktykowanie wycofania i zamknięcia, a ponadto około pięciuset różnych wypowiedzi, które pozwalają $\mathrm{w}$ pewien sposób zrekonstruować jego poglądy. Poza wspomnianą już wyżej wypowiedzią Ana huwwa „Ja jestem nim [Bogiem]”, cytuje się wykrzyknik Subhani! („Chwała mi”). Dla wielu jemu współczesnych były one nie do przyjęcia, gdyż miały świadczyć o przypisywaniu sobie cech boskich, jednak jest to typowy dla mistyków sposób wyrażenia ekstatycznej świadomości (wadżd), która odbiega od zwykłego stanu i niesie ze sobą przekonanie, że mistyk doświadczył kontaktu z boskością. Jak podaje Al-Sahladżi, Al-Bistami miał się domagać, aby wychwalały go anioły, uważał, że tradycyjny kierunek modlitwy, zwany qibla, powinien zostać zmieniony z Mekki na niego samego, a także twierdził, że Al-Kaba w Al-Masdżid al-Haram w Mekce, ważne miejsce w rytuale pielgrzymkowym, krąży wokół niego ${ }^{50}$. Miał też dodawać, że wszystkie stworzenia $\mathrm{z}$ wyjątkiem Boga są jego sługami ${ }^{51}$. Słynne stało się jego twierdzenie, że po połączeniu się z Bogiem zastał jego tron pusty, zatem na nim zasiadł. Utrzymywał też, że on sam nie ma początku ani końca oraz że nie pragnie widzieć Boga, to Bóg pragnie widzieć jego. Miał też twierdzić, że chciałby się znaleźć w piekle, gdyż jest tak potężny, że nie byłoby już tam miejsca dla nikogo innego, a ogień piekielny zgasłby od jego wzroku ${ }^{52}$. Opisuje się także wiele jego nietypowych zachowań wynikających z wielkiej ascezy oraz ciągłych medytacji. Przyczyną tych nietypowych twierdzeń była skrajnie rozumiana miłość do Boga, posunięta aż do granic kwestionowania tauhidu, jednak nie takie było sedno jego twierdzeń. Przypisując sobie doskonałość Bożą, Al-Bistami tym bardziej podkreślał doskonałość i wyjątkowość Boga, który zastępuje ego mistyka. Jego upojenie Bogiem (sukr) było tak wielkie, że twierdził, iż chociaż wypił wszystkie oceany niebieskie i ziemski miłości do Boga, i tak nie ugasił pragnienia swojego uczucia ${ }^{53}$.

Takie przesadne twierdzenia Al-Bistamiego i innych ,pijanych” Bogiem mistyków niekiedy budziły poważne kontrowersje i kończyły się dla ich autorów tragicznie, jak dla Al-Halladża, jednak na ogół mistykom udało się schronić pod wygodną etykietką ,nadwrażliwych” lub „niestabilnych psychicznie". Fakt, że tolerowano ich w społeczeństwie, najlepiej pokazuje, że mimo

${ }^{49}$ Por. Al-Isfahani, Hilijat..., t. 10, s. 34-41, Farid ad-Din Attar, Tazkirat al-aulijja, t. I, s. 134-179 .

${ }^{50}$ Podczas hadżdżu, pielgrzymki do Mekki, która jest jednym z obowiązków każdego muzułmanina, jednym z rytuałów jest tawwaf, czyli siedmiokrotne okrążenie Al-Kaby, stojącej na dziedzińcu meczetu, w kierunku odwrotnym do ruchu wskazówek zegara. Por. Al-Sahladżi, Kitab an-nur, s. 88-89.

51 Tamże, s. 119.

52 Tamże, s. 70, 111.

${ }^{53}$ Al-Hudżwiri, Kaszf al-mahdżub, s. 233. 
wątpliwości co do ekstatycznych zachowań i tego, czy chęć połączenia się człowieka z Bogiem nie narusza Bożego majestatu, mistycyzm muzułmański zawsze zajmował ważne miejsce $\mathrm{w}$ religijności i jest nieodłączną częścią kultury islamu.

\title{
Meditation and Mystical Experience in the Formative Period of Sufism
}

\begin{abstract}
Sufism, Muslim mysticism, is a phenomenon inherent in Islam, existing almost from the beginning of this religion. In the article the view of Islamic sacred texts: the Qur'an and the Hadith, to the basic principles of Sufism: asceticism and meditation is discussed. The most important concepts of Sufism arising during the period of singular mystics, i.e. the formative times of Sufism (9th-11th century) are underlined. Concepts such as love for God, self-accountability, piety, and Union with God were presented and interpreted. Attention was also paid to the biographies of the most important mystics from this period, as recorded in the works of their successors.
\end{abstract}

Keywords: sufism, islam, meditation, ascetism, union with God

Słowa kluczowe: sufizm, islam, medytacja, asceza, połączenie z Bigiem

\section{BIBLIOGRAFIA}

\section{Źródla}

Attar Farid ad-Din, Tazkirat al-aulijja, Katar br.

Al-Charraz, Rasa'il, ed. K. Samarra'i, Bagdad 1967.

Al-Ghazali, Ihja ulum ad-din, t. I-I, Kair br.

Al-Ghazali, Miszkat al-anwar, red. Abd al-Aziz as-Sirwan, Alam al-kutub, Bejrut 1985; pol. thum.

J. Wronecka, Nisza światet, Warszawa 1990.

Al-Halladż, Kitab al-tawasin, red. L. Massignon, Paris 1913.

Ali al-Hudżwiri, Kaszf al-mahdżub, red. W. Zukowski, Tehran 1957, s. 180.

Ibn al-Arabi, Al-Isra ila makam al-asra, Lubnan 1977.

Al-Isfahani, Hilijat al-awlija wa tabakat al-asfija, Dar al-kutub al-ilmijja, Bejrut 1988.

Al-Kuszajri, Risala al-Kuszajrijja fi ilm at-tasawwuf, Alam al-kutub, Al-Kahira 2004.

Al-Muhasibi, Mu'atabat an-nafs, ed. M. Ata, Dar al-Ititam, Al-Kahira, 2015.

As-Sahladżi, Kitab an-nur min kalimat Abi Tajfur, red. A. Badawi, Dar al-kutub al-ilmijja, Al-Kahira 1949, s. 77.

As-Sarradż, Kitab al-luma fi-at-tasawwuf, red. R. Nicholson, Leiden 1914, arabski tekst: http:/ ww.sufi.ir/books/download/farsi/sarraj-toosi/al-luma-fi-tasavof-en-ar.pdf [dostęp: proszę o date].

Al-Sulami, Tabakat as-sufijja, red. N. Szurajba, Dar al-kutub al-ilmijja, Al-Kahira 1952. 


\section{Opracowania}

Awn P., Satan's Tragedy and Redemption. Iblīs in Sufi Psychology, Leiden 1983.

Basharin P., The Problem of Indian Influence on Early Sufism, Proceedings of Three Day International Seminar on Cultural Exchange between India, Iran, Turkey, Afghanistan and Central Asia: Contrubution of Scholars, Sufis and Poets, New Dehli 2016, s. 41-52.

Böwering G., The Mystical Vision of Existence in Classical Islam, Berlin 1980.

Chittick W.C., The Perfect Man as the Prototype of the Self in the Sufism of Jāmī, „Studia Islamica”, 49, 1979, s. 135-157.

Colby F., Narrating Muhammad's Night Journey: Tracing the Development of the Ibn 'Abbas Ascension Discourse, New York 2008.

Cornell R.E., Rabi 'a from Narrative to Myth, London 2019.

Ebstein M., D̄ü l-Nūn Mișrī and Early Islamic Mysticism, „Arabica”, 61, 2014, s. 559-612.

El-Jaichi S., Early Philosophical Sufism: The Neoplatonic Thought of Husayn ibn Manșūr al-Hallāğ, New York 2018.

Encyclopaedia of the Qur'ān, red. J. Dammen McAuliffe, t. I-VI, Leiden 2001.

Fahm A.O., A Brief Analysis on the Meditation on Death in Sufism. With Reference to Al-Ghazāli and al-Rūmī, ,The International Journal of Religion and Spirituality in Society”, 4, 3, 2014, s. 6-14.

Hoyland R., Arabia and the Arabs: From the Bronze Age to the Coming of Islam, London 2001.

Karamustafa A., Sufism: The Formative Period, Edinburgh 2007.

Khamenei S.M., „Man's Creativity/Vicegerency” in Islamic Philosophy and Mysticism, w: Islamic Philosophy and Occidental Phenomenology on the Perennial Issue of Microcosm and Macrocosm, red. A.T. Tymieniecka, Zurich 2019, s. 149-159.

Lubmard J.E.B., From hubb to 'ishq: the Development of Love in Early Sufism, „Journal of Islamic Studies", 18, 3, 2007, s. 345-385.

Massignon L., La Passion de Husayn Ibn Mansûr Hallâj : martyr mystique de l'Islam, exécuté à Bagdad le 26 mars 922: étude d'histoire religieuse, Paris 1975

Morris J.W., The Spiritual Ascension: Ibn 'Arabî and the Mi'râjj, „Journal of the American Oriental Society", 107, 1987, s. 629-652, 108, 1988, s. 63-77.

Pachniak K., Pojęcie światta $w$ islamie. Mistyka światta w traktacie Nisza światel Al-Ghazalego, „Ethos”, 2017, nr 3(119), s. 136-153.

Picken G., Spiritual Purification in Islam. The Life and Works of al-Muhāsibī, London-New York 2011.

Renard J., Knowledge of God in Classical Sufism: Foundations of Islamic Mystical Theology, New York 2004.

Saab N., Mystical Language and Theory of Sufi Writings in the Sufi Writings of Kharrāz, Yale 2004.

Sarrabi-Zadeh S., Practical Mysticism in Islam and Christianity. A Comparative Study of Jalal ad-Din Rumi and Meister Eckhart, London-New York 2016, s. 182-187.

Schimmel A., As Through a Veil: Mystical Poetry in Islam, New York 1982.

Schimmel A., Mystical Dimensions of Islam, Chapel Hill 1975.

Shah-Kazemi R., The Notion and Significance of Ma 'rifa in Sufism, „Islamic Studies”, 13/2, 2002, s. $155-181$.

Sviri S., The Self and its Transformation in Sufism, w: Self and Self-Transormation in the History of Religions, red. D. Shulman, G.G. Stroumsa, Oxford 2002, s. 195-2015.

Wagtendonk K., Fasting in the Koran, Leiden 1968. 